\title{
Biostimulation Potentials of Vigna Species (L.) in Hydrocarbon Impacted Soil
}

\author{
Ismail Haruna Yahaya ${ }^{1,}$, , Riskuwa-Shehu Maryam Lami ${ }^{2}$, Allamin Ibrahim Alkali ${ }^{1}$, \\ Ahmad Ali Farouq ${ }^{2}$, Cathiong Stephen Abakwak ${ }^{1}$ \\ ${ }^{1}$ Department of Microbiology, Faculty of Science, University of Maiduguri, Maiduguri, Nigeria \\ ${ }^{2}$ Department of Microbiology, Faculty of Science, Usmanu Danfodiyo University, Sokoto, Nigeria
}

Email address:

hyismail16@unimaid.edu.ng (I. H. Yahaya)

${ }^{*}$ Corresponding author

\section{To cite this article:}

Ismail Haruna Yahaya, Riskuwa-Shehu Maryam Lami, Allamin Ibrahim Alkali, Ahmad Ali Farouq, Cathiong Stephen Abakwak. Biostimulation Potentials of Vigna Species (L.) in Hydrocarbon Impacted Soil. American Journal of Bioscience and Bioengineering. Vol. 7, No. 1, 2019, pp. 22-27. doi: 10.11648/j.bio.20190701.15

Received: March 3, 2019; Accepted: April 9, 2019; Published: April 29, 2019

\begin{abstract}
Contamination of soil with hydrocarbons is gradually increasing since oil explorations began in Nigeria. With claims of new exploration sites, widespread contamination is possible in many parts of the country in the near future. In view of that, this study aimed to evaluate the growth and phytoremediation potentials of Vigna unguiculata (Cowpea) and Vigna subterrenean (Bambara nut) in hydrocarbon contaminated soil. The study involved a field experiment conducted in a botanical garden under irrigation. The plants were grown on $0 \%, 5 \%$, and $10 \%(\mathrm{v} / \mathrm{w})$ used engine oil contaminated soil in plastic bowls. Percentage emergence of $V$. unguiculata was between $20 \%$ and $100 \%$, while that of $V$. subterrenean was between $50 \%$ and $60 \%$. Phytotoxicity studies showed that the oil was toxic to both plants especially at $10 \%$ oil concentration and $V$. unguiculata was more tolerant than $V$. subterranean. Microbial analyses revealed more bacterial cells as period of treatment increased presumably due to root exudation in the rhizosphere. Eighteen bacterial isolates were identified to belong to Bacillus, Acinetobacter, Klebsiella, Pseudomonas, Enterobacter, Micrococcus, Serratia, Proteus and Staphylococcus genera. All the isolates were found to utilize used engine oil as sole carbon and energy source. The plants and associated bacterial consortium therefore, could be used as important tools in reclaiming soil contaminated with low levels of used engine oil.
\end{abstract}

Keywords: Vigna unguiculata, Vigna subterranean, Phytoremediation, Phytotoxicity, Engine Oil

\section{Introduction}

Used engine oil (UEO) is defined as oil that has been refined from crude oil or any synthetic oil; this has been used and as a result of such use is contaminated by chemical impurities which contribute to chronic hazards including mutagenicity and carcinogenicity as well as environmental hazard [1]. Engine oils are altered during use by vehicles, motor-bikes, generators and other machinery because of the breakdown of additives, contamination with the products of combustion and the addition of metals from the wear and tear of the engine. The major components of UEO consist of aliphatic and aromatic hydrocarbons such as phenol, naphthalene, benzo (a) antracene, benzo (a) pyrene, fluoranthene, lead, cadmium and other potentially toxic metals [2].

UEO is commonly the waste generated by automobile mechanics as a result of servicing and repair of automobile engines. According to Udebuani [3], the wastes generated are dumped by individuals, who may not know the potential human risks of exposure to such pollutants. They therefore dump them in the vicinity, where there is no further treatment and causes environmental risks to humans, animals and plants.

With rapid increase in the automobile density in most developing countries, soil contamination due to used engine oil is at increasing rate. Studies by Udebuani [3] reported that over 1.4 million liters of used engine oil was produced in a Mechanic village in Owerri, Southwestern Nigeria in a year and about $60 \%$ of the mechanics disposed used engine oil on 
land within their immediate environment. This was attributed to lack of awareness of environmental impacts associated with inappropriate used engine oil disposal by the mechanics.

Contamination of soil with toxic substances can degrade its capacity to provide habitat for soil organisms and to grow plants that are safe to eat. Ajayi and Ikporukpo [4] reported that used oil enrich soil with heavy metals. Depletion in the nutrient status (nitrogen and phosphorus), inhibition of microbial activities and degradation of soil physical properties has been reported in hydrocarbon polluted soils [5]. The formation of oily scum which impedes oxygen and availability of water to biota as well as the formation of hydrophobic micro-aggregates with clay surfaces is associated with oil-contaminated soils. Decrease in soil water retention capacity at high potential as a result of oil succeeding water in the competition for pore spaces and reduction in water film thickness around macro-aggregates, are also identified as effects of oil in soil environment [6].

Going by the current trends in the urge for cleaner and sustainable environments attempts are been made to cleanup hydrocarbon contaminated sites worldwide; although in Nigeria, few attempts have so far been made to clean up hydrocarbon contaminated lands. Recent estimates postulated that, over 2000 land-based oil-contaminated sites exist in Nigeria [7] and the most common approach used by the authorities to reclaim some of the sites is remediation by enhanced natural attenuation (RENA) which is considered ineffective due to high pollutants concentration, leaching and unsuitable for remediation of aquifers [8]. With some claims coming from different parts of the country of the availability of oil deposits in commercial quantities, contamination of environments with hydrocarbons will eventually be observed nationwide as soon as exploration starts.

Due to limitations and health risks of physical and chemical technologies used to recover polluted soil; and inefficiency of natural attenuation, phytoremediation remain a promising alternative. Phytoremediation is the name given to a set of technologies that use different plants as a containment, destruction, or an extraction technique. As a remediation technology, phytoremediation has been receiving attention lately, because results from field trials indicate a cost savings as it is based on the concept of using nature to cleanse nature [9]. It is non-intrusive, environment friendly, aesthetically acceptable and could enhance habitat recovery through the stimulation of vigorous vegetative plant growth [10]. With current agricultural revolution in Nigeria, phytoremediation would be essential tool in achieving green environment as well as sustainable agriculture.

Vigna subterrenean (Bambara nut) and Vigna unguiculata (cowpea) are plant species grown in most parts of Africa. They are among the most important leguminous plants grown primarily for their seeds [11]. They are among major pulse crops in Northeastern part of Nigeria cultivated as source of protein. Cowpea is a good growing bulky leguminous crop of high protein content, it is a valuable cash crop, used for improving soil fertility, drought tolerant and adapted to a wide range of soil [12]. Similarly, Bambara nut is an annual, creeping legume with glaborous, trifoliate leaves. It has a deep tap root surrounded by lateral profuse roots bearing nitrogen fixing nodules [13]. Bambara nut is adapted to hot, dry, marginal soils and grows where other legumes cannot grow [14]. In this study, phytoremediation ability of the two plants (Bambara nut and Cowpea) was investigated. This is with a view to providing baseline information for preparing against adversities that might result from mining of petroleum in Chad basin where oil prospecting is been intensified. The area is known for its agricultural activities and its contribution to Nigerian food security through Cowpea and Bambara nut cultivation. With experience of environmental degradation through hydrocarbon contamination in some regions in the country, adequate majors need to be in place for such eventuality.

\section{Materials and Methods}

\subsection{Study Site}

The experiment was carried out at the Botanical Garden Udom Essien Court, University of Maiduguri, Maiduguri (Long. $13.16^{\circ}$ E; Lat. $11.85^{\circ}$ North), Borno State, Northeastern Nigeria. Seeds of Vigna unguiculata and Vigna subterrenean were obtained from commercial area in the University and authenticated at Herbarium, Department of Biological Sciences, University of Maiduguri. While the used engine oil used in this study was obtained from Oando filling station along Bama road, Maiduguri, Borno state.

\subsection{Experimental Design}

In this experiment, a complete randomized design was used. Three sets of 2 plastic bowls were arranged and properly labeled as $\mathrm{A}, \mathrm{B}$ and $\mathrm{C}$ accordingly. Soil with no previous history of hydrocarbon contamination was obtained from the botanical garden, University of Maiduguri; weighed and placed into the plastic bowls. The bowls were perforated at the sides and bases to avoid water logging and also to increase the soil aeration. To each of the two bowls of group A through $\mathrm{C}, 2 \mathrm{~kg}$ of soil was weighed and placed into each of the plastic bowls. Groups A and B soils were contaminated with used engine oil by adding $200 \mathrm{ml}$ and $100 \mathrm{ml}$ to achieve $10 \% \mathrm{v} / \mathrm{w}$ and $5 \% \mathrm{v} / \mathrm{w}$ contamination level respectively. The bowls in group $\mathrm{C}$ were left uncontaminated to serve as controls. The set-up was allowed to acclimatize for one week and after the acclimatization period; viable seeds of Vigna unguiculata (cowpea) were planted and monitored for plant emergence and growth. Similar experimental set-up was concurrently made to support the growth of Vigna subterrenean (Bambara nut).

\subsection{Phytotoxicity Study}

After sowing, the soil was irrigated daily and emergence was observed subsequently. Parameters such as day of emergence, percentage emergence, shoot length and leaf length were determined at the interval of 2 weeks for 1 month. Percentage germination (number of seedlings that sprouted / 
number of seeds planted $\times 100$ ) and days taken to germinate were calculated by counting from the day of apparent emergence of ridicules. Lengths of shoots were measured using metre rule and leaves were counted manually. Based on the data obtained from the above parameters, phytotoxicity of used engine oil was evaluated using this relation [15]:

$$
\text { Percentage toxicity }(\%)=\frac{\text { Parameter of Control }- \text { Parameter of Treatment }}{\text { Parameter of Control }} \times 100
$$

\subsection{Bacteriological Analysis}

Soil samples were aseptically collected from the rhizosphere of both plants for enumeration of total heterotrophic and oil utilizing bacteria as described by [16]. Total heterotrophic bacteria were enumerated by inoculating serially diluted $\left(\times 10^{8}\right)$ soil samples in nutrient agar (Oxoid) after 24 hours incubation while used engine oil degrading bacteria were enumerated and subsequently isolated by inoculating similar dilution into oil agar (composed of $1.2 \mathrm{~g}$ $\mathrm{KH}_{2} \mathrm{PO}_{4}, 1.8 \mathrm{~g} \quad \mathrm{~K}_{2} \mathrm{HPO}_{4} 4.0 \mathrm{~g} \quad \mathrm{NH}_{4} \mathrm{Cl}, 0.2 \mathrm{~g} \quad \mathrm{MgSO}_{4} .7 \mathrm{H}_{2} \mathrm{O}$, $0.1 \mathrm{gNaCl}, 0.01 \mathrm{~g} \mathrm{FeSO}_{4} .7 \mathrm{H}_{2} \mathrm{O}$ and $20 \mathrm{~g}$ agar per liter at $\mathrm{pH}$ 7.4) supplemented with $0.1 \%$ UEO, after 5 days. The isolates were identified based on colonial, morphological and biochemical characteristics according to the schemes of [17, 18]. The isolates were screened for ability to utilize the UEO by inoculating aliquot (McFarland 8) into broth containing $0.1 \%$ UEO for fifteen (15) days. Change in turbidity was used as measure of bacterial utilization of UEO with uninoculated broth as control.

\subsection{Statistical Analysis}

Analysis of variance was used to establish statistical significance of the data generated and significant values were separated using DMR test. GraphPad InStat 3 statistical package was used for the analysis.

\section{Results and Discussion}

The biostimulation potentials of Vigna subterranean and Vigna unguiculata in hydrocarbon impacted soil were investigated. Plant emergence started 7 and 9 days after sowing $V$. unguiculata and $V$. subterrenean respectively. The number of plants that emerged was low when compared with the number of seeds planted at $10 \%$ contamination level. Results in Figure 1 shows that the percentage emergence of the plants ranged between $60 \%$ and $50 \%$ in $V$. subterranean with higher rate been observed in uncontaminated soils. In the case of $V$. unguiculata, significant difference was observed between the seeds sown in $0 \%$ and $10 \%$ UEO contaminated soil where the emergence rate was $100 \%$ and $20 \%$ respectively. Contamination of soil with hydrocarbons results to serious changes in soil physicochemical properties and may influence plant growth and development. Studies by [19] reported that the presence of spent engine oil in plant micro-environment affects the germination of Cajanus cajan, Vigna subterrenean and Phaseolus vulgaris in-vitro. It is established that hydrocarbon contamination leads to reduction in nutrient release and uptake as well as soil moisture, thus affecting germination.

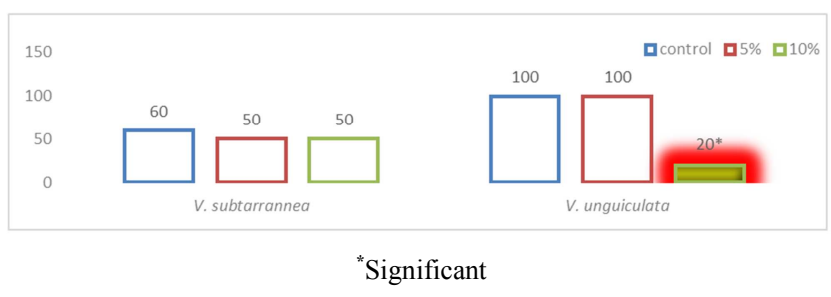

Figure 1. Percentage emergence of radicles.

Figure 2 shows the plant growth parameters. Longer shoots were observed in uncontaminated soil with $5.2 \mathrm{~cm}$ and $10.4 \mathrm{~cm}$ length in $V$. subterranean and $V$. unguiculata respectively. Similarly, more number of leaves were recorded in the uncontaminated soil whereas fewer leaves where observed in $10 \%$ UEO contamination in both plants. There was significant difference in both plants between plant parameters of the control and 10\% UEO contaminated soil.

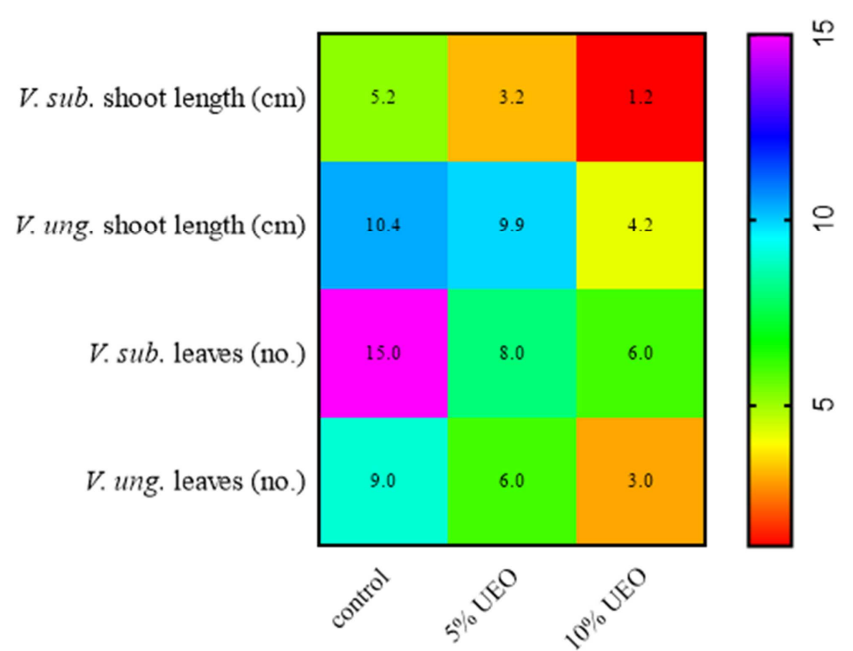

Figure 2. Plants'growth parameters after 4 weeks.

Results in Table 1 shows the level of toxicity the UEO posed to the Vigna species. Emergence of $V$. subterrenean was affected by $16.6 \%$ and its shoot length and leaves were most affected (77\% and $60 \%$ respectively) at $10 \%$ contamination level. Similar trend was observed in $V$. unguiculata except during emergence where $80 \%$ toxicity was observed (Table 2). Based on this result, it is evident that UEO had phytotoxic effect on the germination and growth of these plant species especially at higher contamination level. This might be attributed to the fact that some oil fractions have high wetting capacity and penetrating power, which result to destruction of seed coat and embryo leading to loss of seed viability. Studies by [20] have reported the phytotoxic effect of spent engine oil on Dolichos lablab and Abelmoschus esculentus due to its wetting and penetration 
ability. At 5\% UEO contamination, $V$. unguiculata was most tolerant as compared to other treatments. This might be linked to cumulative effects of species differences and level of hydrocarbon contamination. This is in accordance with the findings of [21], who observed that oil effects on plants are species and variety dependent.

Table 1. Toxicity of UEO on V. subterranean.

\begin{tabular}{llll}
\hline Treatment (\% & \multicolumn{2}{l}{ Phytotoxicity $(\%)$} & \\
\cline { 2 - 4 } UEO) & Emergence & Shoot length & Number of leaves \\
\hline 5 & 16.6 & 38.5 & 46.7 \\
10 & 16.6 & 77 & 60.0 \\
\hline
\end{tabular}

Table 2. Toxicity of UEO on V. unguiculata.

\begin{tabular}{llll}
\hline Treatment (\% & \multicolumn{2}{l}{ Phytotoxicity $(\%)$} \\
\cline { 2 - 4 } UEO) & Emergence & Shoot length & Number of leaves \\
\hline 5 & 0.0 & 4.8 & 33.3 \\
10 & 80.0 & 59.6 & 63.3 \\
\hline
\end{tabular}

Enumeration of bacteria in soil samples before planting showed that there was high number of total heterotrophic bacteria especially in uncontaminated soil (control); however it decreased with increased UEO contamination as shown in Table 3. The bacterial counts ranged from $7.6 \times 10^{9} \mathrm{cfu} / \mathrm{g}$ to $9.8 \times 10^{9} \mathrm{cfu} / \mathrm{g}$ immediately after contamination and from 1.8 $\times 10^{9} \mathrm{cfu} / \mathrm{g}$ to $6.4 \times 10^{9} \mathrm{cfu} / \mathrm{g}$ after seven days of exposure to UEO. In the oil utilizing bacteria (OUB) however, more number of bacteria were observed seven days after contamination except in $10 \%$ UEO contaminated oil where the least number $\left(1.0 \times 10^{9} \mathrm{cfu} / \mathrm{g}\right)$ was recorded. Immediately after contamination, the bacterial count ranged from $2.3 \times 10^{9}$ $\mathrm{cfu} / \mathrm{g}$ to $2.8 \times 10^{9} \mathrm{cfu} / \mathrm{g}$ in which $5 \%$ contaminated soil had the highest count.

Bacterial counts determined after plant emergence shows that there were large number of bacteria in the rhizosphere soil. In $V$. unguiculata, total heterotrophic bacteria (THB) ranged between $5.9 \times 10^{9} \mathrm{cfu} / \mathrm{g}$ and $9.0 \times 10^{9} \mathrm{cfu} / \mathrm{g}$ two weeks after emergence. Considerable increase in THB count was observed in subsequent weeks where a count reaching up to $2.98 \times 10^{10} \mathrm{cfu} / \mathrm{g}$ was recorded. Similar observation was also made in oil utilizing bacterial (OUB) counts. The number of bacteria ranged between $2.4 \times 10^{9} \mathrm{cfu} / \mathrm{g}$ in the second week and $1.72 \times 10^{10} \mathrm{cfu} / \mathrm{g}$ in the fourth week. Likewise, there was considerable increase in THB counts in the rhizosphere of $V$. subterranean from second week to the fourth week. Highest increase was observed in 5\% UEO contaminated soil where there was four fold increase (from $9.1 \times 10^{9} \mathrm{cfu} / \mathrm{g}$ in the second week to $3.59 \times 10^{10} \mathrm{cfu} / \mathrm{g}$ in the fourth week). In addition, higher increase was also observed in OUB at the same contamination level as shown in Table 4. The marked increase in bacterial counts observed in this study might be associated with plants' influence in the rhizosphere through root exudation. Plants provide root exudates of carbon, energy, nutrients, enzymes and sometimes oxygen to microbial populations in the rhizosphere [22]. Root exudates of sugars, alcohols and acids can amount to $10 \%$ to $20 \%$ of plant photosynthesis annually [23] and provide sufficient carbon and energy to support large numbers of microbes (e.g., approximately $10^{8}-10^{9}$ vegetative microbes per gram of soil) in the rhizosphere [24]. Due to these exudates, microbial populations and activities are 5 to 100 times greater in the rhizosphere than in the bulk soil [25].

The percentage of oil degrading bacteria is presented in Table 5. The result shows that there were many oil degraders in the uncontaminated rhizosphere $(68 \%)$ of $V$. subterranean than the contaminated rhizosphere $(10.5 \%-43 \%)$. In contrast, contaminated rhizosphere $(62.5 \%-65 \%)$ of $V$. unguiculata had more hydrocarbon degraders than the uncontaminated soil (39.2\%). However, more of the organisms were observed in the fourth week than the second week. It is believed that legumes and grasses may stimulate pollutant degrading communities capable of utilizing different types of hydrocarbons. Studies have found that Poly-aromatic hydrocarbons $(\mathrm{PAH})$ degraders are enhanced in legume over non-legume rhizosphere while alkane degrading populations are enhanced in grasses compared to legume [26].

Table 6 shows the frequency distribution of the identified isolates. Eighteen bacteria were identified based on their morphological and biochemical traits. Bacillus species were observed most (22.2\%), followed by Acinetobacter (16.7\%). Other isolates identified including Staphylococcus, Enterobacter and Klebsiella which had $11.1 \%$ rate of occurrence each. The remaining species were Pseudomonas, Micrococcus, Corynebacterium, Proteus and Serratia with 5.5\% of occurrence each. Previous studies have shown that there is a great diversity of microbes in rhizosphere of different plants. The diversity and structure of bacterial communities is plant-specific and varies over time. Diversity of bacteria is affected by the plant age, the season and the soil conditions [27]. However, the effect of rhizosphere bacteria depends mostly on the genotype of the microorganisms and plants involved as well as on the environmental conditions [28].

The oil degradation test revealed that all the isolates were capable of utilizing UEO as sole carbon and energy source. However, the degree of oil utilization varied among species after 15 days incubation under the same environmental conditions. Majority of the isolates could utilize the oil moderately whereas many could use the oil luxuriantly. Table 7 shows the nature of oil utilization by the isolates using turbidity as measure of degradation.

Table 3. Bacterial count before planting.

\begin{tabular}{|c|c|c|c|c|}
\hline \multirow{3}{*}{ Treatment (\% UEO) } & \multicolumn{4}{|c|}{ Bacterial count at period of contamination $\left(\times 10^{8} \mathrm{cfu}\right)$} \\
\hline & \multicolumn{2}{|c|}{ Total Heterotrophic Bacteria (THB) } & \multicolumn{2}{|c|}{ Oil Utilizing Bacteria (OUB) } \\
\hline & 0 days & 7 days & 0 days & 7 days \\
\hline 0 & 98 & 64 & 27 & 43 \\
\hline 5 & 90 & 45 & 28 & 37 \\
\hline 10 & 76 & 18 & 23 & 10 \\
\hline
\end{tabular}


Table 4. Bacterial counts after emergence.

\begin{tabular}{|c|c|c|c|c|c|c|c|c|}
\hline \multirow{4}{*}{$\begin{array}{l}\text { Treatment } \\
\text { (\% UEO) }\end{array}$} & \multicolumn{8}{|c|}{ Bacterial count $\left(\times 10^{8} \mathrm{cfu} / \mathrm{g}\right)$} \\
\hline & \multicolumn{4}{|c|}{ Vigna unguiculata } & \multicolumn{4}{|c|}{ Vigna subterranean } \\
\hline & THB & & OUB & & THB & & OUB & \\
\hline & 2 weeks & 4 weeks & 2 weeks & 4 weeks & 2 weeks & 4 weeks & 2 weeks & 4 weeks \\
\hline 0 & 59 & 224 & 24 & 172 & 90 & 152 & 33 & 104 \\
\hline 5 & 90 & 217 & 33 & 164 & 91 & 358 & 22 & 160 \\
\hline 10 & 65 & 298 & 46 & 156 & 172 & 186 & 43 & 28 \\
\hline
\end{tabular}

\section{Conclusion}

This study demonstrated that used engine oil is phytotoxic to Vigna unguiculata and Vigna subterrenean most especially above 5\% contamination level. Despite the tolerance of Vigna unguiculata to low UEO contamination, its germination and subsequent emergence was worst affected. It was observed that the plant species played a vital role in increasing the bacterial population two weeks after emergence, thus buttressing their biostimulation potentials. Although the plants were able to stimulate bacterial growth, future contamination of soil in Lake Chad basin would affect crop production in the area leading to economic and food challenges. Hence, the need for concerted efforts towards pollution abatements in future is paramount.

Table 5. Percentage of hydrocarbon degraders.

\begin{tabular}{|c|c|c|c|c|}
\hline \multirow{2}{*}{ Treatment (\% UEO) } & \multicolumn{2}{|c|}{ V. subterranean (\% degraders) } & \multicolumn{2}{|c|}{ V. unguiculata $(\%$ degraders) } \\
\hline & 2 weeks & 4weeeks & 2 weeks & 4weeeks \\
\hline 0 & 26.6 & 68 & 39.2 & 39.2 \\
\hline 5 & 25 & 43 & 41 & 65 \\
\hline 10 & 10.5 & 32.5 & 18.5 & 62.5 \\
\hline
\end{tabular}

Table 6. Frequency distribution of bacterial isolates.

\begin{tabular}{ll}
\hline Identified isolate (species) & Rate of occurrence (\%) $\mathbf{n}=\mathbf{1 8}$ \\
\hline Bacillus & 22.2 \\
Acinetobacter & 16.7 \\
Staphylococcus & 11.1 \\
Enterobacter & 11.1 \\
Klebsiella & 11.1 \\
Pseudomonas & 5.5 \\
Micrococcus & 5.5 \\
Corynebacterium & 5.5 \\
Proteus & 5.5 \\
Serratia & 5.5 \\
\hline
\end{tabular}

Table 7. Hydrocarbon degradation by the isolates.

\begin{tabular}{|c|c|c|c|}
\hline \multirow{2}{*}{ Isolates } & \multicolumn{3}{|c|}{ Growth in UEO medium } \\
\hline & 5days & 10days & 15days \\
\hline Klebsiella sp. A21 & + & + & + \\
\hline Enterobacter sp. A22 & + & + & + \\
\hline Bacillus sp. A31 & + & + & + \\
\hline Serratia sp. A32 & + & ++ & + \\
\hline Proteus sp. B11 & ++ & ++ & ++ \\
\hline Corynebacterium sp. B12 & ++ & ++ & ++ \\
\hline Bacillus sp. B13 & ++ & ++ & + \\
\hline Acinetobacter sp. B111 & + & ++ & ++ \\
\hline Acinetobacter sp. B112 & ++ & ++ & ++ \\
\hline Micrococcus sp. B113 & + & ++ & +++ \\
\hline Klebsiella sp. B21 & + & ++ & + \\
\hline Enterobacter sp. B22 & + & ++ & +++ \\
\hline Pseudomonas sp. B221 & ++ & ++ & +++ \\
\hline Corynebacterium sp. C11 & + & + & +++ \\
\hline Bacillus sp. C12 & ++ & ++ & +++ \\
\hline Staphylococcus sp. C21 & + & ++ & ++ \\
\hline Bacillus sp. C22 & ++ & ++ & +++ \\
\hline Staphylococcus sp. C23 & + & ++ & +++ \\
\hline
\end{tabular}

+ Minimum ++ Moderate +++ Maximum

\section{References}

[1] Blodgett, W. C. 2001. Water Soluble Mutagens Produced During the Bioremediation of Oil Contaminated Soil. Florida Scientist.60 (1): 28-36.

[2] Ugoh, S. C. and Moneke, L. U., 2011. Isolation of Bacteria from Engine Oil Contaminated soils in Auto mechanic workshops in Gwagwalada, Abuja, FCT Nigeria. Academia Arena 3(5):28-33.

[3] Udebuani, A. C., Okoli, C. G., Okoli, I. C., Nwigwe, H. C. and Ozoh, P. T. E. 2011. Assessments of the Volume and Disposal Methods of Spent Engine Oil Generated in Nekede Mechanic village, Owerri, Nigeria. Reportand Opinion 3(2):31-36.

[4] Ajayi, D. D., Ikporukpo, C. O., 2005. An analysis of Nigeria's environmental vision 2010. J. Environ. Policy Plan. 7, 341-365.

[5] Altas, R. M. and Bartha, R., 1993. Stimulated biodegradation of oil slicks using oleophilic fertilizers." Environmental Science Technology.7:538-541.

[6] Udom, B. E. and Nuga, B. O. 2011. Characterization of Soil Health Using Microbial Community and Maize Germination as Bioindicatorsin Oil-Contaminated Soil. Journal of Advances in Developmental Research 2 (2):191-197.

[7] Ite, A. E., Ibok, U. J., Ite, M. U. and Petters, S. W. 2013. Petroleum Exploration and Production: Past and Present Environmental Issues in the Nigeria's Niger Delta. Nature 1,78-90.

[8] Sam, K., Coulon, F. and Prpich, G. 2017. Management of petroleum hydrocarbon contaminated sites in Nigeria: Current challenges and future direction. Land use policy; 64:133-144.

[9] Nwaichi, E. O, Frac, M, Nwoha, P. A. and Eragbor, P. 2015. Enhanced phytoremediation of Crude oil-polluted soil by four plant species: effect of inorganic and organic bioaugumentation. Int. J. Phytoremediation 17(12): 1253-1261. 
[10] Lee, K., Doe, K. G., Lee, L. E. J., Suidan, M. T., Venosa, A. D. 2001. Remediation of an oil contaminated experimental freshwater wetland: Habitat recovery and toxicity reduction. Proceedings of the 2001 International Oil Spill Conference. American Petroleum Institute, Washington, DC.

[11] Howell, J. A., W. H. Eshbaugh, S. Guttman and E. Rabakonandrianina, 1994. Common names given to bambara groundnut (Vigna subterranea) in Madagascar. Econ. Bot., 48:217-221.

[12] Johnson, C. R and Scow, K. M. 1999. Effect of nitrogen and phosphorous addition on phenanthrene biodegradation in four soils. Biodegradation 10, 43-50.

[13] Dakora, F. D. and Phillips, D. A. 2002. Root Exudates as Mediators of Mineral Acquisition in Low-Nutrient Environments. Plant and Soil 245: 35-47.

[14] Brink, M, Romalemana, G. M, Sibuga, K. P. 2006. Vigna subterrenean (L) Verde. Record from Protobase.

[15] Ibrahim, S. and Nafi'u, S. A. 2017. In vitro Effects of Tannery Effluents on Seed Germination and Growth Performance of Maize (Zea mays), Spinach (Spinacia caudatus) and Lettuce (Lactuca sativa). International Journal of Applied Biological Research; 8(1): 160-173.

[16] Ismail, H. Y., Ijah, U. J. J., Riskuwa, M. L. and Ibrahim A. A. 2014. Biodegradation of spent engine oil by bacteria isolated from the rhizosphere of legumes grown in contaminated soil. International Journal of Environment; 3(2):85-97.

[17] Barrow, G. I. and Feltham, K. A. 1993. Cowan and Steel's Manual for Identification of Medical Bacteria. $3^{\text {rd }}$ edition. Cambridge University Press, London.

[18] Holt, J. G., Krieg, N. R., Sneath, P. H. A., Stately, J. T. and Williams, St. 1994. Bergey's manual of determinative bacteriology, 9th ed, Baltimore, Williams and Wilkins.

[19] Osuagwu, A. N. and Iwuoha, C. L. 2015. Assessment of Spent Engine Oil on the Germination Ability of Cajanus cajan, Vigna subterranean and Phaselous vulgaris. International
Conference on Advances in Agricultural, Biological \& Environmental Sciences (AABES-2015) July 22-23, 2015 London (UK).

[20] Kathi, S. and Khan, A. B. 2011. Toxicity of spent oil contaminants on Dolichos lablab L. and Abelmoschus esculentus L. The Ecoscan; 4(1):133-136.

[21] Agbogidi, O. M. 2010. Response of six cultivars of cowpea Vigna unguiculata ((L) (Walp) to spent engine oil. African Journal of food science and technology 1 (6): 139-142.

[22] Cunningham, S. D., Anderson, T. A., Schwab, P. A. and Hsu, F. C. 1996. Phytoremediation of Soils Contaminated with Organic Pollutants. Advances in Agronomy, 56:55-114.

[23] Schnoor, J. L., Licht, L. A., McCutcheon, S. C., Wolfe, N. L. and Carreira, L. H. 1995. Phytoremediation of organic and nutrient contaminants. Environmental Science and Technology 29 (7): 318-323.

[24] Erickson, L. E., Davis, L. C. and Muralidharan, N. 1995. Bioenergetics and Bioremediation of Contaminated Soil. Thermochimica Acta.250: 353-358.

[25] Aprill, W. and Sims, R. C. 1990. Evaluation of the Use of Prairie Grasses for Stimulating Polycyclic Aromatic Hydrocarbon Treatment in soil. Chemosphere 20:253-265.

[26] Philips, A. L. 2008. The relationship between plants and their root-associated microbial communities in hydrocar-bon phytoremediation systems. Saskatoon: University of Saskatchewan; 2008. 144 p.

[27] Hrynkiewicz, K., Baum, C., Niedojadło, J. and Dahm, H. 2009. Promotion of Mycorrhiza Formation and Growth of Willows by the Bacterial Strain Sphingomonassp. 23L on Fly Ash. Biology and Fertility of Soil 45:385-394.

[28] Brimecombe, M. J., De Leij, F. A. M. and Lynch, J. M. 2007. Rhizodeposition and Microbial Populations. In: R. Pinton., Z. Varanini. and P. Nannipieri. (eds) The Rhizosphere: Biochemistry and Organic Substances at the Soil-plant Interface. CRC Press, Taylor \& Francis Group, New York, pp. 73-109. 